\title{
Extraordinary Opportunity: Genes and the Environment
}

National Cancer Institute

\section{Source}

National Cancer Institute. Extraordinary Opportunity: Genes and the Environment. NCI

Thesaurus. Code C16132.

Goal: identify and characterize every major human gene that predisposes people to cancer; beg in to apply these discoveries throug h clinical practice to help patients at risk; address the psychosocial, ethical, and legal issues associated with inherited cancer susceptibility (NCI Web) 